\title{
Exploratory Investigation of Chitosan as Mordant for Eco-Friendly Antibacterial Printing of Cotton with Natural Dyes
}

\author{
M. D. Teli, Javed Sheikh, and Pragati Shastrakar \\ Department of Fibers and Textile Processing Technology, Institute of Chemical Technology, Mumbai 400019, India \\ Correspondence should be addressed to M. D. Teli; textileudct@yahoo.com
}

Received 27 May 2013; Accepted 7 August 2013

Academic Editor: Gajanan S. Bhat

Copyright (C) 2013 M. D. Teli et al. This is an open access article distributed under the Creative Commons Attribution License, which permits unrestricted use, distribution, and reproduction in any medium, provided the original work is properly cited.

\begin{abstract}
Although a lot of antibacterial finishes are available for cotton, the user safety and durability of the finish are always the important issues. Some of the natural dyes are known to possess antibacterial properties; however, most of them are nonsubstantive. Hence, they are used in conjunction with eco-friendly natural mordants. Although metallic mordants are effective, they are environmentally pollutants, hence not desirable. In the current work, the novel natural mordant like chitosan with different concentrations $(10 \%$ and $20 \%$ of weight of fiber) was applied on cotton and fabric was printed with natural dyes such as catechu, turmeric, and marigold using screen printing method. All the three dyes were used in powder form in print paste with different concentrations $(1 \%, 5 \%$, and $10 \%)$ and guar gum was used as thickener. The printed samples using chitosan as a mordant showed the equivalent color values to that of prints obtained using alum as a mordant. The printed fabric showed excellent antibacterial activity against both gram-positive and gram-negative bacteria. The method may be considered suitable for eco-friendly printing and antibacterial finishing of textile materials.
\end{abstract}

\section{Introduction}

Textiles, especially those made of natural fibers, are an excellent medium for the growth of microorganisms when the basic requirements for their growth such as nutrients, moisture, oxygen, and appropriate temperature are present. The large surface area and ability to retain moisture of textiles also assist the growth of microorganisms on the fabric [1]. The growth of microorganisms on textiles inflicts a range of unwanted effects not only on the textile itself but also on the wearer. These effects include the generation of unpleasant odor, stains, discoloration in the fabric, a reduction in the tensile strength of the fabric, and an increased likelihood of contamination [2]. In the last few decades, with the increase in new antimicrobial fiber technologies and the growing awareness about cleaner surroundings and healthy lifestyle, a range of textile products based on synthetic antimicrobial agents, such as triclosan, metal and their salts, organometallics, phenols, and quaternary ammonium compounds, have been developed and quite a few are also available commercially [3]. Even though the excellent antimicrobials are available, their user ecology is always a question. Some of the natural dyes are reported to possess antimicrobial properties.
Synthetic dyes are here to remain as one can tailor make them depending upon the required hue, substantivity, and fiber. The development of synthetic dyes at the beginning of the twentieth century led to a more complete level of quality and more reproducible techniques of application. As a result, a distinct lowering in the dyestuff costs per $\mathrm{kg}$ of dyed goods was achieved [4]. Also, a full gamut of color is available for application on various types of fibers.

However, during the last few decades, the use of synthetic dyes is gradually receding due to an increased environmental awareness and harmful effects, of either toxic degraded products or their nonbiodegradable nature. In addition to previously mentioned, some serious health hazards like allergenicity and, carcinogenicity are associated with some of the synthetic dyes based on azo chromophores. As a result, a ban has been imposed all over the world including European Economic Community (EEC), Germany, USA, and India on the use of some synthetic dyes (e.g., azodyes) which finally triggered active research and development to revive world heritage and traditional wisdom of employing safer natural dyes [5]. Consumers nowadays are becoming more and more concerned about environmental issues and hence are demanding 
for natural product incorporating natural ingredient. Due to increasing awareness of environmental issues and pollution controls, natural dyes are gaining importance as they are obtained from renewable resources and they present no health hazards and some of them sometimes act as a health care product [6]. Hence, it is important to understand that, although natural colors cannot substitute use of synthetic dyes completely, there is definitely increasing market for such complete eco-friendly dyed or printed materials.

Natural dyes with a few expectations are nonsubstantive and hence must be used in conjunction with mordants. Mordant is a chemical, which can fix itself on the fiber and also combines with the dyestuff. The challenge before the natural dyers in application of natural color is the necessity to us metallic mordants which themselves are pollutant and harmful. Due to the environmental hazard caused by metallic mordant while dyeing of textile fabric, dyers are always looking for safe natural mordant for natural dyes. In this paper, this issue of screening a natural mordant for printing is explored.

The main objective of printing is to produce colored patterns with sharp boundaries on textile materials without any dye spreading beyond the boundaries of the motif of design [7]. Although a lot of research has been reported in the area of printing and natural dyeing of textiles, the research in the area of natural dye printing is reported to a limited extent. Also application of natural dye prints as antibacterial finish has also remained unexplored. The applications of chitosan for different applications in textiles are reported [8-24], but the application of such functional biopolymer as a mordant in natural dyeing has been quite rare in the literature. In the current work, chitosan extracted from waste shrimp shells [24] was utilized as a mordant for simultaneous natural dye printing and antibacterial finishing of cotton in comparison with commonly used metal mordants. The efficacy of chitosan as ecofriendly mordant and antibacterial finish has been studied. The antibacterial activity against both gram-positive and gram-negative bacteria has also been screened.

\section{Materials and Methods}

2.1. Materials. Chitosan (mol. wt. 124999.8 , degree of deacetylation, $89.06 \%$, nitrogen content, 7.1\%) was extracted from waste shrimp shells [24] and used for the study. Ready for dyeing (RFD) Cotton fabric (Plain weave, EPI-69, PPI-88, GSM122.95) was purchased from the market. Catechu, turmeric, and marigold were purchased from the market. All other chemicals used were of laboratory grade.

\subsection{Methods}

2.2.1. Preparation of Mordant. Stock solutions of alum and $\mathrm{CuSO}_{4}$ were made by dissolving in double distilled water. Chitosan was dissolved in aqueous acetic acid (20 grams per liter, gpl). Chitosan powder was added to acetic acid solution followed by warming at $60^{\circ} \mathrm{C}$ for $2 \mathrm{~h}$ with continuous stirring using mechanical stirrer.

2.2.2. Preparation of Dye for Printing. All the dyes used were first converted to powder form. For this purpose, catechu, turmeric, and marigold were first dried in an oven at $50^{\circ}$ for $24 \mathrm{~h}$ and later grinded in mixer grinder. The powder so obtained was filtered through the 60 mesh nylon fabric. The fine powder of natural dye was used for printing.

2.2.3. Mordanting of Cotton Fabric. Mordanting of cotton was carried out with different mordants at two different concentrations on the weight of fabric (alum; $10 \%$ and 20\%, copper sulphate; $1 \%$ and $2 \%$, and chitosan; $10 \%$ and $20 \%$ ) at $90^{\circ} \mathrm{C}$ for 60 mins with material to liquor ratio as $1: 30$. The mordanted fabric was squeezed and dried in open width form at $100^{\circ} \mathrm{C}$ for 5 mins and then used for printing.

2.2.4. Printing. The stock paste of guar gum was prepared using $2 \%$ of guar gum powder. The guar gum powder was sprinkled slowly in water with continuous stirring in order to prevent lump formation. The paste was stirred continuously at $90^{\circ} \mathrm{C}$ for $1 \mathrm{~h}$.

The print paste was prepared in different dye concentrations $(1 \%, 5 \%$, and $10 \%)$ on the basis of print paste. For preparation of $1 \%$ of print paste, $1 \mathrm{gm}$ of dye powder was first pasted with small quantity of water followed by addition of $99 \mathrm{gm}$ of guar gum stock paste. The print paste was continuously stirred for 30 mins. The mordanted cotton fabrics were then printed with two strokes of squeeze, steamed at $102^{\circ} \mathrm{C}$ for 10 mins. The samples were washed with water and then dried in air.

\subsection{Analysis of Printed Fabrics}

2.3.1. Color Value by Reflectance Method. The printed samples were evaluated for the depth of color by reflectance method using 10-degree observer. The absorbance of the dyed samples was measured on Spectraflash SF 300 (Datacolor International, USA) equipped with reflectance accessories. The $K / S$ values were determined using expression

$$
\frac{K}{S}=\frac{(1-R)^{2}}{2 R},
$$

where $R$ is the reflectance at complete opacity, $K$ is the absorption coefficient, $S$ is the Scattering coefficient

Dyed fabrics were simultaneously evaluated in terms of CIELAB color space $\left(L^{*}, a^{*}\right.$ and $\left.b^{*}\right)$ values using the Rayscan Spectrascan $5100+$. In general, the higher the $K / S$ value, the higher the depth of the color on the fabric. $L^{*}$ corresponding to the brightness $(100=$ white, $0=$ black $), a^{*}$ to the red-green coordinate $(+\mathrm{ve}=\mathrm{red},-\mathrm{ve}=$ green $)$, and $b^{*}$ to the yellow-blue coordinate $(+\mathrm{ve}=$ yellow, $-\mathrm{ve}=$ blue $)$. As a whole, a combination of all these parameters enables one to understand the tonal variations.

2.3.2. Washing Fastness. Evaluation of color fastness to washing was carried out using ISO II methods [25]. A solution containing $5 \mathrm{gpl}$ soap solution was used as the washing liquor. The cotton samples were treated for $45 \mathrm{~min}$ at $50^{\circ} \mathrm{C}$ using material to liquor ratio of $1: 50$ in rota machine. After rinsing and drying, the change in color of the sample and staining on the undyed samples was evaluated on the respective standard 
TABLE 1: Effect of mordants and catechu concentration on color strength of cotton.

\begin{tabular}{|c|c|c|c|c|c|c|c|c|}
\hline \multirow{2}{*}{ Mordant (\%) } & \multirow{2}{*}{$\begin{array}{c}\text { Catechu } \\
(\%)\end{array}$} & \multirow{2}{*}{$\begin{array}{c}\text { Colour value } \\
K / S\end{array}$} & \multicolumn{3}{|c|}{ CIE colour coordinates } & \multicolumn{2}{|c|}{ Washing fastness } & \multirow{2}{*}{ Light fastnes } \\
\hline & & & $L^{*}$ & $a^{*}$ & $b^{*}$ & Change & Staining & \\
\hline \multicolumn{9}{|l|}{ Alum } \\
\hline 10 & 1 & 0.2514 & 81.626 & 4.566 & 8.739 & 5 & 5 & 6 \\
\hline 10 & 5 & 0.6024 & 83.211 & 4.991 & 11.255 & 5 & $4-5$ & 7 \\
\hline 10 & 10 & 1.0746 & 83.757 & 5.434 & 12.167 & $4-5$ & $4-5$ & 7 \\
\hline 20 & 1 & 0.299 & 82.104 & 3.562 & 8.851 & $4-5$ & $4-5$ & 6 \\
\hline 20 & 5 & 0.5852 & 83.216 & 5.055 & 11.454 & $4-5$ & 4 & 7 \\
\hline 20 & 10 & 1.1067 & 83.842 & 5.752 & 12.448 & 4 & 4 & 7 \\
\hline \multicolumn{9}{|l|}{ Chitosan } \\
\hline 10 & 1 & 0.3363 & 79.477 & 4.235 & 9.042 & 5 & 5 & 6 \\
\hline 10 & 5 & 0.5287 & 78.845 & 6.323 & 8.972 & 5 & 5 & 6 \\
\hline 10 & 10 & 1.0201 & 79.248 & 7.689 & 10.13 & $4-5$ & $4-5$ & 7 \\
\hline 20 & 1 & 0.4182 & 78.529 & 4.718 & 7.628 & $4-5$ & $4-5$ & 7 \\
\hline 20 & 5 & 0.8044 & 79.117 & 7.286 & 9.349 & $4-5$ & $4-5$ & 7 \\
\hline 20 & 10 & 1.3245 & 79.183 & 8.214 & 9.867 & $4-5$ & 4 & 7 \\
\hline \multicolumn{9}{|c|}{ Copper sulphate } \\
\hline 1 & 1 & 0.7087 & 72.994 & 6.824 & 14.267 & $4-5$ & 5 & 7 \\
\hline 1 & 5 & 1.6571 & 71.891 & 9.586 & 13.176 & $4-5$ & $4-5$ & 7 \\
\hline 1 & 10 & 3.0619 & 73.111 & 9.882 & 14.614 & $4-5$ & 4 & 7 \\
\hline 2 & 1 & 0.6359 & 72.575 & 6.913 & 13.488 & 4 & $4-5$ & 7 \\
\hline 2 & 5 & 3.7264 & 73.109 & 10.569 & 14.928 & 4 & 4 & 7 \\
\hline 2 & 10 & 3.7948 & 72.734 & 10.114 & 14.604 & $4-5$ & 4 & 8 \\
\hline
\end{tabular}

TABLE 2: Effect of mordants and turmeric concentration on color strength of cotton.

\begin{tabular}{|c|c|c|c|c|c|c|c|c|}
\hline \multirow{2}{*}{ Mordant (\%) } & \multirow{2}{*}{ Turmeric (\%) } & \multirow{2}{*}{$\begin{array}{c}\text { Colour value } \\
K / S\end{array}$} & \multicolumn{3}{|c|}{ CIE colour coordinates } & \multicolumn{2}{|c|}{ Washing fastness } & \multirow{2}{*}{ Light fastness } \\
\hline & & & $L^{*}$ & $a^{*}$ & $b^{*}$ & Change & Staining & \\
\hline \multicolumn{9}{|l|}{ Alum } \\
\hline 10 & 1 & 0.8084 & 84.007 & -4.01 & 33.849 & $4-5$ & $4-5$ & 3 \\
\hline 10 & 5 & 4.3847 & 89.655 & 2.389 & 43.257 & $4-5$ & 4 & 3 \\
\hline 10 & 10 & 5.9102 & 90.404 & 1.295 & 44.146 & 4 & 4 & 3 \\
\hline 20 & 1 & 0.937 & 84.934 & 4.716 & 35.625 & 4 & $3-4$ & 3 \\
\hline 20 & 5 & 3.7634 & 90.364 & 3.028 & 44.609 & $4-5$ & $3-4$ & 3 \\
\hline 20 & 10 & 7.9375 & 91.327 & 3.129 & 45.076 & 4 & 4 & 4 \\
\hline \multicolumn{9}{|l|}{ Chitosan } \\
\hline 10 & 1 & 1.1319 & 83.174 & 5.348 & 39.866 & 5 & $4-5$ & 3 \\
\hline 10 & 5 & 2.4573 & 84.203 & 1.755 & 42.078 & $4-5$ & $4-5$ & 4 \\
\hline 10 & 10 & 6.3261 & 86.902 & 1.418 & 45.928 & $4-5$ & 4 & 4 \\
\hline 20 & 1 & 1.1838 & 81.587 & 3.784 & 37.307 & 4 & 4 & 3 \\
\hline 20 & 5 & 2.4426 & 84.3 & 0.586 & 42.285 & 4 & $3-4$ & 3 \\
\hline 20 & 10 & 6.6156 & 87.28 & 1.097 & 46.202 & 4 & 4 & 4 \\
\hline \multicolumn{9}{|c|}{ Copper sulphate } \\
\hline 1 & 1 & 0.6626 & 81.256 & 3.234 & 27.299 & $4-5$ & 4 & 5 \\
\hline 1 & 5 & 2.6011 & 87.844 & 3.495 & 37.35 & $4-5$ & 4 & 5 \\
\hline 1 & 10 & 5.0764 & 89.695 & 4.177 & 39.489 & $4-5$ & $3-4$ & 5 \\
\hline 2 & 1 & 0.7542 & 82.015 & 3.598 & 28.505 & 4 & $3-4$ & 5 \\
\hline 2 & 5 & 4.0985 & 88.032 & 2.253 & 37.751 & $3-4$ & $3-4$ & 5 \\
\hline 2 & 10 & 7.3138 & 89.973 & -3.06 & 40.382 & 4 & $3-4$ & 6 \\
\hline
\end{tabular}


TABLE 3: Effect of mordants and marigold concentration on color strength of cotton.

\begin{tabular}{|c|c|c|c|c|c|c|c|c|}
\hline \multirow{2}{*}{ Mordant (\%) } & \multirow{2}{*}{ Marigold (\%) } & \multirow{2}{*}{$\begin{array}{c}\text { Colour value } \\
K / S\end{array}$} & \multicolumn{3}{|c|}{ CIE colour coordinates } & \multicolumn{2}{|c|}{ Washing fastness } & \multirow{2}{*}{ Light fastness } \\
\hline & & & $L^{*}$ & $a^{*}$ & $b^{*}$ & Change & Staining & \\
\hline \multicolumn{9}{|l|}{ Alum } \\
\hline 10 & 1 & 1.1593 & 81.411 & 2.234 & 32.553 & 5 & $4-5$ & 6 \\
\hline 10 & 5 & 3.6119 & 85.186 & -1.16 & 36.621 & $4-5$ & 4 & 6 \\
\hline 10 & 10 & 6.2023 & 86.014 & 1.086 & 37.852 & $4-5$ & $3-4$ & 7 \\
\hline 20 & 1 & 1.1186 & 80.382 & -1.66 & 31.881 & $4-5$ & $3-4$ & 6 \\
\hline 20 & 5 & 4.3349 & 85.02 & 0.058 & 37.712 & 4 & $3-4$ & 7 \\
\hline 20 & 10 & 7.2649 & 86.29 & 0.494 & 38.388 & $4-5$ & 4 & 7 \\
\hline \multicolumn{9}{|l|}{ Chitosan } \\
\hline 10 & 1 & 1.3023 & 72.346 & 1.266 & 21.601 & 5 & 5 & 7 \\
\hline 10 & 5 & 2.2313 & 76.981 & 0.533 & 24.224 & 5 & $4-5$ & 7 \\
\hline 10 & 10 & 3.4716 & 78.828 & 2.247 & 28.088 & $4-5$ & $4-5$ & 7 \\
\hline 20 & 1 & 1.5061 & 74.502 & 0.916 & 23.481 & 5 & $4-5$ & 7 \\
\hline 20 & 5 & 3.5484 & 78.269 & 2.107 & 26.801 & $4-5$ & $4-5$ & 7 \\
\hline 20 & 10 & 4.561 & 78.963 & 3.354 & 28.089 & $4-5$ & 4 & 7 \\
\hline \multicolumn{9}{|c|}{ Copper sulphate } \\
\hline 1 & 1 & 1.0403 & 74.96 & 2.073 & 22.475 & 5 & 5 & 7 \\
\hline 1 & 5 & 3.0923 & 78.166 & 1.362 & 26.119 & 5 & 5 & 7 \\
\hline 1 & 10 & 7.7622 & 81.004 & 0.148 & 29 & $4-5$ & $4-5$ & 7 \\
\hline 2 & 1 & 1.4072 & 75.411 & 1.78 & 23.091 & 4 & 4 & 7 \\
\hline 2 & 5 & 4.9077 & 79.504 & 1.514 & 28.381 & $4-5$ & 4 & 7 \\
\hline 2 & 10 & 12.4811 & 82.349 & 0.323 & 30.92 & 4 & 4 & 7 \\
\hline
\end{tabular}

scales (rating 1:5; where 1: poor; 2: fair; 3: good; 4: very good and 5: excellent).

2.3.3. Light Fastness. Printed cotton fabric was tested for color fastness to light according to ISO 105/B02 [26]. The light fastness was determined using artificial illumination with Xenon arc light source, Q-Sun Xenon Testing Chamber with black standard temperature of $65^{\circ} \mathrm{C}$ with relative humidity of the air in the testing chamber as $40 \%$ and daylight filter, wavelength, $k=420 \mathrm{~nm}$. The cotton samples were compared with the standard scale of blue wool reading (ratings, 1:8; where 1: poor; 2: fair; 3:moderate; 4: good; 5: better; 6: very good; 7: best and 8: excellent). The color fastness to light was measured using test method.

2.3.4. Determination of Antibacterial Activities of Printed Fabrics. The antibacterial activity of the printed fabrics was estimated by AATCC Test Method 100-2004 [27].

\section{Results and Discussion}

3.1. Color Values of Natural Dye Printed Cotton. The efficacy of chitosan as mordant was screened in comparison with metal mordants and the results are summarized in Tables 1, 2 , and 3 .

The initial attempt was to explore the role of chitosan as a mordant for the localised coloration (printing) with natural dyes in the study. For this purpose, the cotton fabric was printed with all the three dyes with and without mordants.
The prints were very light in shade and the color bled heavily after washing where mordants were absent. However, in case of chitosan, like other metal mordants, the color values obtained were higher and the prints were washed fast and this trend was valid for all the three dyes studied. The observations confirmed the role of chitosan as a mordant in natural dye printing. The role of chitosan as a mordant may be attributed to the presence of amino groups which get protonated and offer the sites for attachment of the dye which is mainly anionic in nature. The mechanism of dye attachment to the fiber is similar to that in case of metal mordants.

The mordant concentrations used were 10 and 20\% for alum and chitosan and $1 \%$ and $2 \%$ for $\mathrm{CuSO}_{4}$. The results in Tables 1-3 indicate the dye specific trends of color values. In case of catechu as a dye, $\mathrm{CuSO}_{4}$ showed the highest color values among the mordants. However, the color values for chitosan and alum mordants were comparable. In case of turmeric, alum mordant showed highest color values while in case of marigold $\mathrm{CuSO}_{4}$ showed highest color values. The varying combinations of mordant and dye resulted in different shades and tones of dyed cotton fabric. In case of all the dyes and mordant combinations, keeping the dye concentration constant, the increasing mordant concentrations resulted in increasing color values. The same trend was valid when dye concentration was varied keeping mordant concentration constant.

The fastness properties of the printed cotton fabrics were studied and the results are presented in Tables 1-3 which indicate the comparative fastness properties in the case of all the mordants. The only dyed samples showed much inferior 
TABLE 4: Effect of mordant and dye combinations on antibacterial properties.

\begin{tabular}{|c|c|c|c|c|c|}
\hline \multirow{2}{*}{ Mordant } & \multirow{2}{*}{ Mordant conc. (\%) } & \multirow{2}{*}{ Dye } & \multirow{2}{*}{$\begin{array}{c}\text { Dye conc. } \\
\text { (\% of print paste) }\end{array}$} & \multicolumn{2}{|c|}{ Bacterial reduction $^{\$}(\%)$} \\
\hline & & & & S. aureus & E. coli \\
\hline Alum & 20 & \multirow{3}{*}{ Catechu } & 10 & 98.25 & 97.50 \\
\hline Chitosan & 20 & & 10 & 99.75 & 99.80 \\
\hline $\mathrm{CuSO}_{4}$ & 2 & & 10 & 100 & 100 \\
\hline Alum & 20 & \multirow{3}{*}{ Turmeric } & 10 & 98.25 & 97.00 \\
\hline Chitosan & 20 & & 10 & 99.25 & 99.10 \\
\hline $\mathrm{CuSO}_{4}$ & 2 & & 10 & 100 & 100 \\
\hline Alum & 20 & \multirow{3}{*}{ Marigold } & 10 & 99.50 & 99.00 \\
\hline Chitosan & 20 & & 10 & 99.90 & 99.75 \\
\hline $\mathrm{CuSO}_{4}$ & 2 & & 10 & 100 & 100 \\
\hline
\end{tabular}

$\$$ Represents average value of 3 determinations.

fastness properties which were improved with mordanting (irrespective of the type) which indicate the positive role of mordant in holding the dye on fabric. The improvements in fastness properties with mordant concentration clearly indicate the positive role of mordants in case of natural dyes. The washing fastnesses obtained varied in the range of good to excellent grades. Light fastness was found to be improving with improving $\mathrm{K} / \mathrm{S}$ values. $\mathrm{CuSO}_{4}$ showing very high light fastness as well as high degree of antibacterial activity which may be attributed to its positive contribution in improving the stability of dye-metal complex to light as well as its known toxic nature.

3.2. Antibacterial Activity of Printed Cotton Fabric. The quantitative antibacterial assessment was made using AATCC100(2004) test method and the results are presented in Table 4.

The results for mordanted and printed fabrics indicate the excellent antibacterial activity for all the mordants. The cotton fabric showed no antibacterial activity against both $S$. aureus and E. coli.

As far as antibacterial activity is concerned, the chitosan mordanted samples showed comparative antibacterial activity with that of $\mathrm{CuSO}_{4}$ and higher activity than that of alum in case of all the dyes studied. Chitosan is known for antibacterial activity against broad spectrum bacteria and mechanism of antibacterial activity was explained by researchers [12, 28]. The chitosan hence can be claimed as eco-friendly mordant cum antibacterial finishing agent for cotton.

\section{Conclusion}

The concept of printing of cotton fabric with natural dyes in fine powder form was successfully carried out using chitosan as an eco-friendly mordant. The color values varied with the dye mordant combination; however, the chitosan mordant showed good color values. The excellent antibacterial activity was displayed by the printed samples. The printed cotton also displayed excellent fastness properties. The role of chitosan as a mordant in natural dye printing has been confirmed through this study. The proof of demonstration of concept sample can open door for further research to develop antibacterial printed cotton using natural dyes.

\section{Conflict of Interests}

The authors do not have any stake in Data color international or AATCC and their names appear in the paper purely in coincidental and academic nature. Their reference is made to indicate a standard equipment and test method were made use of in this work and in no way it advocates these brands.

\section{References}

[1] W. Su, S. S. Wei, S. Q. Hu, and J. X. Tang, "Antimicrobial finishing of cotton textile with nanosized silver colloids synthesized using polyethylene glycol," Journal of the Textile Institute, vol. 102, no. 2, pp. 150-156, 2011.

[2] Y. Gao and R. Cranston, "Recent advances in antimicrobial treatments of textiles," Textile Research Journal, vol. 78, no. 1, pp. 60-72, 2008.

[3] M. Joshi, S. W. Ali, R. Purwar, and S. Rajendran, "Ecofriendly antimicrobial finishing of textiles using bioactive agents based on natural products," Indian Journal of Fibre and Textile Research, vol. 34, no. 3, pp. 295-304, 2009.

[4] T. Bechtold, A. Turcanu, E. Ganglberger, and S. Geissler, "Natural dyes in modern textile dyehouses-how to combine experiences of two centuries to meet the demands of the future?" Journal of Cleaner Production, vol. 11, no. 5, pp. 499-509, 2003.

[5] J. K. Kumary and A. K. Sinha, "Resurgence of natural colourants: a holistic view," Natural Product Letters, vol. 18, no. 1, pp. 59-84, 2004.

[6] K. H. Prabhu, M. D. Teli, and N. G. Waghmare, "Eco-friendly dyeing using natural mordant extracted from Emblica officinalis G. Fruit on cotton and silk fabrics with antibacterial activity," Fibers and Polymers, vol. 12, no. 6, pp. 753-759, 2011.

[7] V. A. Shenai, Technology of Printing, Sevak Publications, Mumbai, India, 1985.

[8] J. A. Rippon, "Improving the dye coverage of immature cotton fibres by treatment with chitosan," Journal of the Society of Dyers and Colourists, vol. 100, no. 10, pp. 298-303, 1984.

[9] S.-H. Lim and S. M. Hudson, "Application of a fibre-reactive chitosan derivative to cotton fabric as a zero-salt dyeing auxiliary," Coloration Technology, vol. 120, no. 3, pp. 108-113, 2004. 
[10] S.-H. Lim and S. M. Hudson, "Application of a fiber-reactive chitosan derivative to cotton fabric as an antimicrobial textile finish," Carbohydrate Polymers, vol. 56, no. 2, pp. 227-234, 2004.

[11] S. K. Tiwari and M. M. Gharia, "Characterization of chitosan pastes and their application in textile printing," AATCC Review, vol. 3, p. 25, 2003.

[12] Z. Zhang, L. Chen, J. Ji, Y. Huang, and D. Chen, "Antibacterial properties of cotton fabrics treated with Chitosan," Textile Research Journal, vol. 73, no. 12, pp. 1103-1106, 2003.

[13] S. Sharaf, K. Opwis, D. Knittel, and J. S. Gutmann, "Comparative investigations on the efficiency of different anchoring chemicals for the permanent finishing of cotton with chitosan," Autex Research Journal, vol. 11, no. 2, pp. 71-77, 2011.

[14] K. El-Tahlawy, "Chitosan phosphate: a new way for production of eco-friendly flame-retardant cotton textiles," Journal of the Textile Institute, vol. 99, no. 3, pp. 185-191, 2008.

[15] K. F. El-Tahlawy, M. A. El-Bendary, A. G. Elhendawy, and S. M. Hudson, "The antimicrobial activity of cotton fabrics treated with different crosslinking agents and chitosan," Carbohydrate Polymers, vol. 60, no. 4, pp. 421-430, 2005.

[16] T. Oktem, "Surface treatment of cotton fabrics with chitosan," Coloration Technology, vol. 119, no. 4, pp. 241-246, 2003.

[17] A. Abou-Okeil, A. El-Shafie, and A. Hebeish, "Chitosan phosphate induced better thermal characteristics to cotton fabric," Journal of Applied Polymer Science, vol. 103, no. 3, pp. 2021-2026, 2007.

[18] B. N. Bandyopadhyay, G. N. Sheth, and M. M. Moni, "Chitosan can cut salt use in reactive dyeing," International Dyer, vol. 183, no. 11, pp. 39-42, 1998.

[19] R. S. Davidson and Y. Xue, "Improving the dyeability of wool by treatment with chitosan," Journal of the Society of Dyers and Colourists, vol. 110, no. 1, pp. 24-29, 1994.

[20] S. Rattanaphani, M. Chairat, J. B. Bremner, and V. Rattanaphani, "An adsorption and thermodynamic study of lac dyeing on cotton pretreated with chitosan," Dyes and Pigments, vol. 72, no. 1, pp. 88-96, 2007.

[21] M. Jassal, R. B. Chavan, R. Yadav, and P. Singh, "Chitosan as thickner for printing of cotton with pigment colors," in Chitin and Chitosan: Opportunities \& Challenges, P. K. Dutta, Ed., vol. 94, SSM International Publication, Contai, India, 2005.

[22] S. A. Bahmani, G. C. East, and I. Holme, "The application of chitosan in pigment printing," Journal of the Society of Dyers and Colourists, vol. 116, no. 3, pp. 94-99, 2000.

[23] M. D. Teli and J. Sheikh, "Simultaneous pigment dyeing and antibacterial finishing of denim fabric using Chitosan as a binder," International Dyer, vol. 197, no. 4, p. 28, 2012.

[24] M. D. Teli and J. Sheikh, "Extraction of chitosan from shrimp shells waste and application in antibacterial finishing of bamboo rayon," International Journal of Biological Macromolecules, vol. 50, no. 5, pp. 1195-1200, 2012.

[25] E. R. Trotmann, Dyeing and Chemical Technology of Textile Fibers, Charles Griffin and Company, London, UK, 1984.

[26] ISO technical manual, Geneva, Switzerland, 2006.

[27] "American Association of Textile Chemists and Colorists," AATCC Technical Manual 76, AATCC, Research Triangle Park, NC, USA, 2007.

[28] S.-H. Lim and S. M. Hudson, "Review of chitosan and its derivatives as antimicrobial agents and their uses as textile chemicals," Journal of Macromolecular Science, vol. 43, no. 2, pp. 223-269, 2003. 

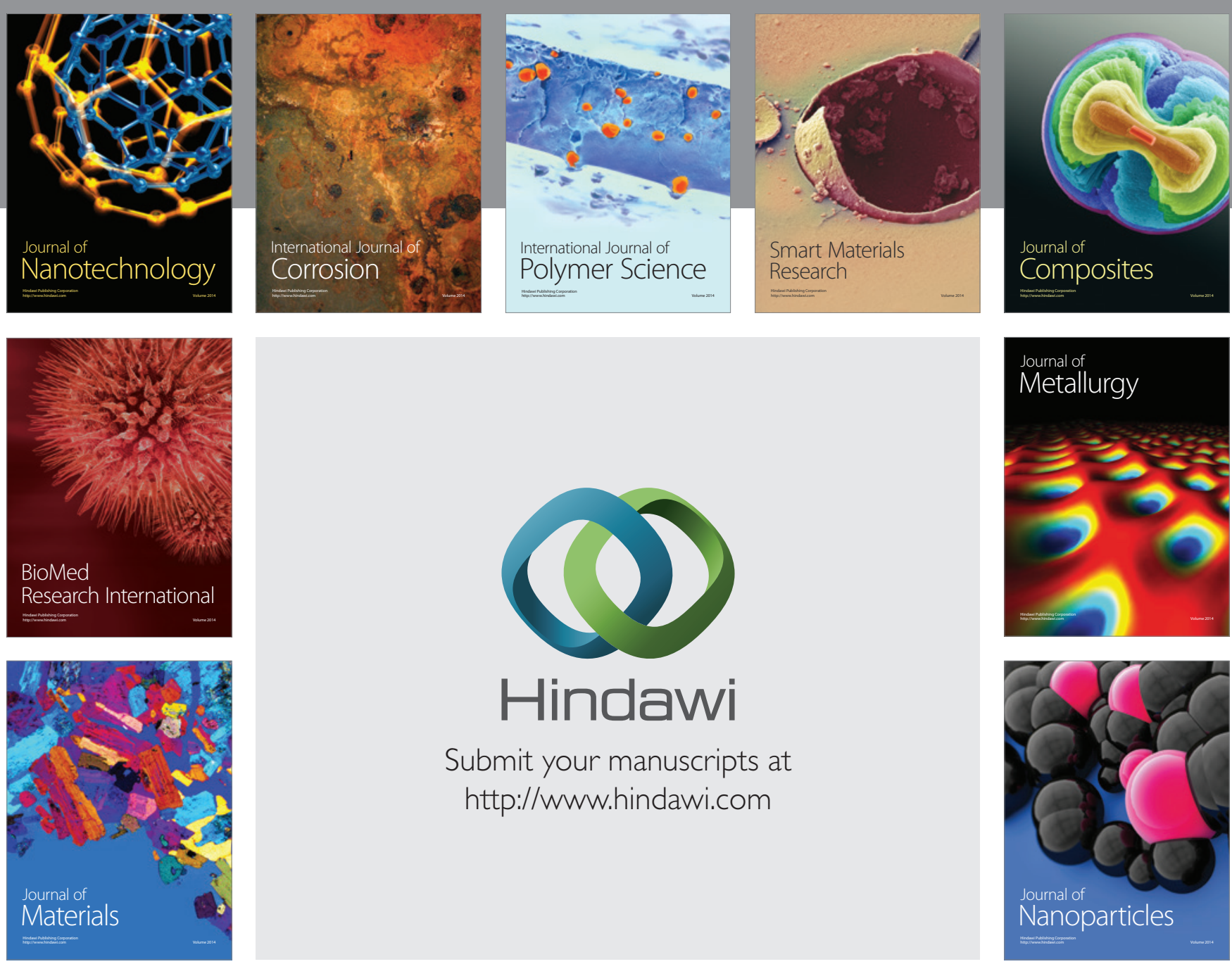

Submit your manuscripts at http://www.hindawi.com
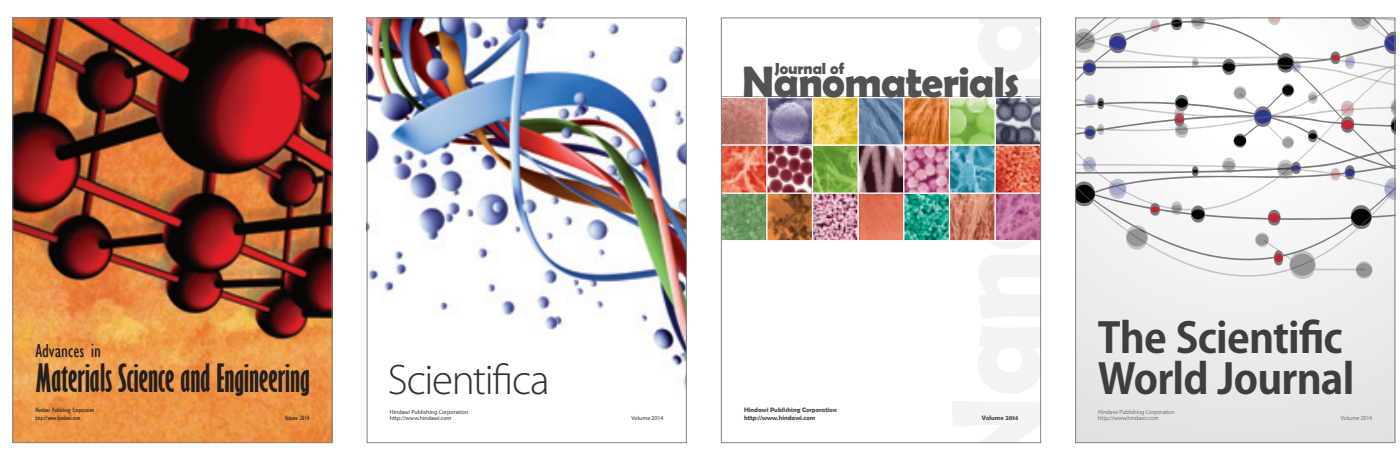

\section{The Scientific World Journal}
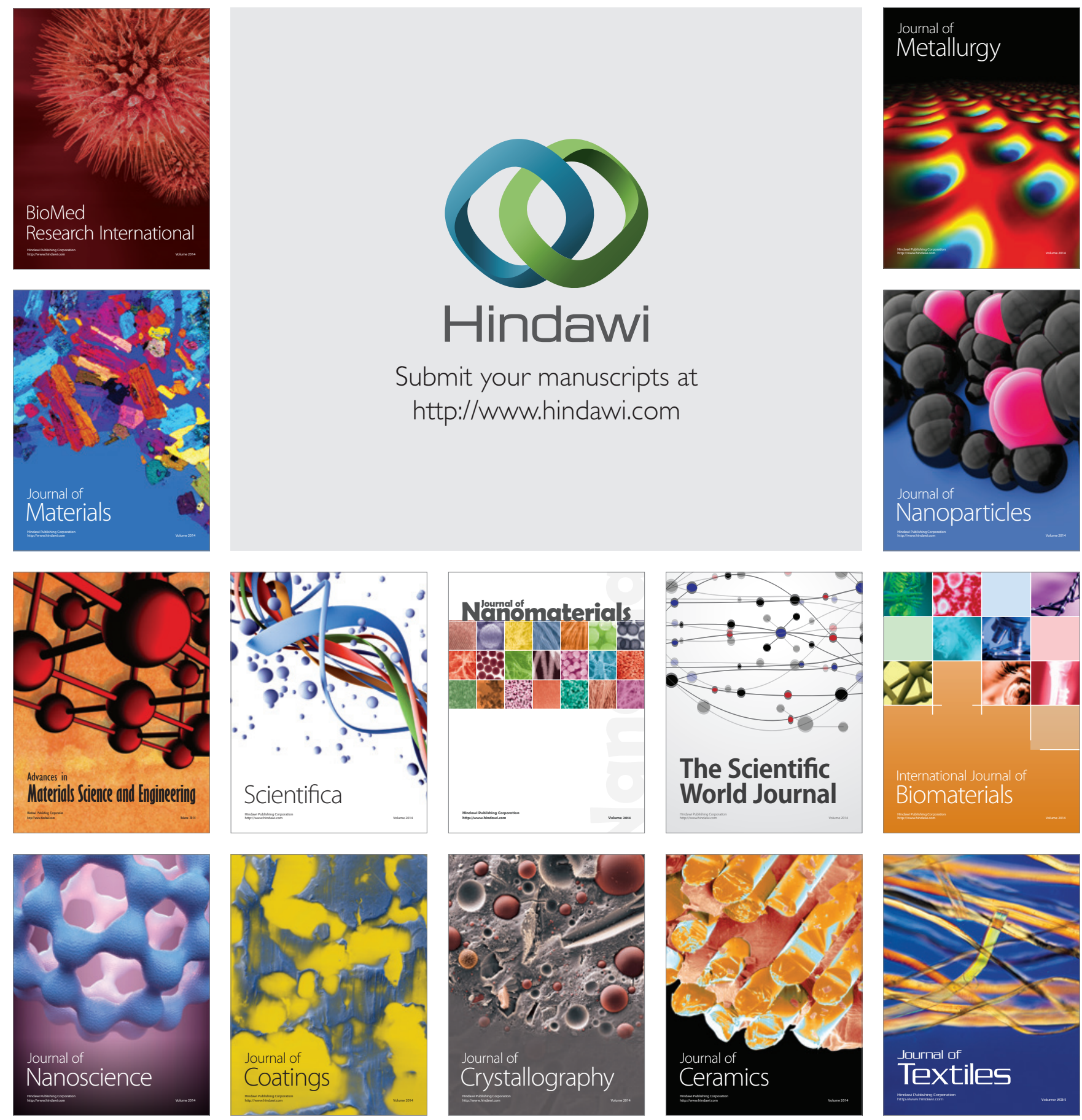